\title{
SETTLER SOCIETY AND POSTCOLONIAL APOLOGIES IN AUSTRALIA AND NEW ZEALAND
}

\author{
Jennifer Lawn
}

\begin{abstract}
From the 1990 on onward, collective apologies for historical injustices proliferated in political arenas across the globe, usually in response to intense activism by wronged parties or their descendants. Addressing this turn to symbolic reconciliation, I ask how such apologies might realign relationships between the Crown, indigenous communities, and settler society, with particular focus on apologies for the stolen generations of Aboriginal and Torres Strait Islander children forcibly removed from their families in Australia, and on Treaty of Waitangi settlements in Aotearoa New Zealand. Interpretations of collective apologies as purely calculable, impossible, or self-interested transactions are rejected. Instead, I regard apologies as a powerful mode of discourse capable not only of acknowledging wrongdoing on the part of State authorities, but also of generating new forms of historical consciousness and collective identity within settler society. However, the extent of settler engagement in the politics of collective apologies varies greatly between Australia and New Zealand.
\end{abstract}

\section{INTRODUCTION}

Observing a recent 'spate of apologies for the mistakes of the past', Deborah Montgomerie asks:

The personal is, as the slogan goes, political. But does that mean that the converse is true too? Should we extend the courtesies and conventions of personal life to politics by apologising for our collective misdemeanours? ... Is this a matter of etiquette or intellectual substance? (2003:4).

Montgomerie is referring to the late twentieth-century proliferation of restitution cases in which official bodies, governments, and institutions apologise for 
their roles in committing large-scale historical injustices. This 'Age of Apology' has been affirmed as a neo-Enlightenment morality (Barkan 200o), as the necessary symbolic corollary to material restitution (Hodge and O'Carroll 2006:117), and a confirmation of civility (Grace 2001). ${ }^{1}$ Conversely, official apologies have also been decried as hypocritical (Hirst 2006: 80); 'vacuous', 'exhibitionistic', and 'politically expedien[t]' (Beauchamp 2007); ineffective, to the extent that by apologising, collective agents such as governments purport to take on the affective characteristics of individual subjects (Trouillot 2000); and defeated by their own success, to the extent that the mass production of apologies undermines their essential gravitas and exceptionality. However, my goal in this paper is not to ask whether such apologies are 'good' or 'bad' as a general category; as a matter of practical reality, apologies have become a recognised tool of international statecraft and domestic politics (as is the tenor of the extensive discussion in Marrus 2006). Instead, I want to take up Montgomerie's query as to whether the politics of restitution can be 'taken personally' with regard to the triangular relationships between government, settler society, and indigenous claimants. My examples will be drawn from the postcolonial contexts of collective apologies for the stolen generations of indigenous children in Australia and Crown apologies for historical breaches of the Treaty of Waitangi in Aotearoa New Zealand. ${ }^{2}$

I will proceed from the basis that apologies are unusually powerful and dynamic modes of utterance. Apologies are called for within emotionally laden contexts; as Sara Ahmed suggests, they not only reference feelings of guilt and shame, but also raise anxiety because they open up the past and keep open the future (2004:116). As speech acts, apologies are designed to formalise a new level of relationship between the apologiser and the injured party, but this transaction can fail on many grounds: improper formulation, insincere intentions, or lack of standing on the part of the apologiser, and refusal to accept the apology on the part of those to whom it is addressed. As political gestures, official apologies are often included within restitution or compensation settlements that have been fought for by dispossessed groups; but they may also serve as bargaining chips, by which politicians give or withhold apologies to win favours with constituencies that they perceive as furthering their own interests.

As a historical phenomenon, apology movements coalesced in the late twentieth century from the conjunction of two grand narratives of late modernity: a rejuvenated jurisprudence of natural justice, and the emergence of what I will term, after Ian Parker, 'psychodynamic culture. ${ }^{3}$ Such narratives not only provide a set of terms and concepts to frame debates about the role of collective 
apologies, but also establish the conditions under which the act of apologising itself can make sense and take political effect. Natural justice advances the tenet that formally constituted laws can be held to account against universal values founded on inherent human dignity. Such rights are increasingly being extended to disadvantaged ethnic groups, and an important realisation is developing that universal values are hollow unless pinned to local social commitments (Barkan 2000:309). The United Nations' advocacy of the concept of the crime against humanity has been further instrumental in this movement. 'Psychodynamic culture' revolves around the episteme that 'what has been forgotten is what forms our character' (Ian Hacking, cited in Antze and Lambek 1996:65). Routinely extrapolating from the individual psyche to that of the nation, psychodynamic culture generates a set of ideas that have become truisms in reconciliation movements as a projection of collective healing: that unspoken histories amount to a kind of amnesia in a national psyche, one which continues its pathological effects until the stories of victims are not simply documented but actually told, heard, commemorated and ritualised with appropriate feeling. Within the psychodynamic perspective, these conditions of reception are necessary before painful aspects of the past have any prospect of being integrated into the national story.

My aim in placing apology movements in these larger discursive contexts is not to diminish or relativise their particular political and ethical force. In fact, both Maori and indigenous Australian advocates have strategically appealed to these discourses, with considerable success. Instead, I seek to show how discourse operates, sometimes in various forms of combination, to open some avenues of possibility while closing others. In particular, when viewed as transactions between peoples and across generations, liberal concepts of apology as an essentially personal mode can founder against the delimited sense of moral agency that tends to dominate Western constructions of selfhood. According to the liberal perspective, collective apologies are logically impossible on the basis that the responsibility for any injustice, and hence the capacity to apologise for it, rests solely with the person(s) who committed the wrongful action in question. Those who elevate personal responsibility above more communitarian values are thus likely to equivocate about national apologies, and I locate examples in two highly publicised speeches by political leaders, Don Brash in New Zealand and John Howard in Australia. I then introduce two lines of thought which revisit, without fully resolving, the liberal conundrum. The first arises from the domain of civil religion and addresses the role of apology as ritual; here I develop further the argument of Danielle Celermajer, that apology can be interpreted as a form of political covenant which engages settler society as well as the government and aggrieved indigenous groups. The sec- 
ond line of inquiry develops from the concept of transferential history, which I will broach by analogy with Dominick LaCapra's mediation of the relationship between history and memory. At this speculative level of analysis, collective apologies have the potential to produce discursive effects in the strong sense of the term, not merely describing but actually inscribing new modalities of social responsibility and group identity. However, the political impact of collective apologies has also varied greatly between Australia and New Zealand, countries which have, it seems to me, developed cultures of collective apology along almost precisely inverse lines.

TAKING IT PERSONALLY: BRASH, HOWARD, AND THE LIBERAL SELF

A representative expression of the settler politics of apology in New Zealand can be found in Don Brash's Orewa speech of 27 January 2004, delivered when he was leader of the National Party opposition. ${ }^{4}$ Brash broadly supports the principle of 'fix [ing] the wrongs of the past' (5), but he also appeals to elements of Pakeha resentment at perceived special privileges allowed to Maori:

Let me be quite clear. Many things happened to the Maori people that should not have happened. There were injustices, and the Treaty process is an attempt to acknowledge that, and to make a gesture at recompense. But it is only that. It can be no more than that.

None of us was around at the time of the New Zealand wars. None of us had anything to do with the confiscations. There is a limit to how much any generation can apologise for the sins of its great grandparents (Brash 2004:5-6, emphasis in original).

The statement enacts a masterly, though insidious, slippage between the constative dimension (what the words say) and the rhetorical dimension (what the words do, in the sense of swaying Brash's predominantly Pakeha audience). At the constative level, Brash concedes the reality of historical injustice and expresses goodwill toward reparative measures. He notes the undeniable truth, in a literal sense, that no New Zealanders of the present generation lived in the nineteenth century, although many breaches of Treaty principles occurred much more recently than that. But Brash also creates a phantom antagonist. He implicitly positions Maori as insatiably demanding some undefined 'more' than this gesture at compensation. The 'us' who are subject to the demand are implicitly Pakeha New Zealanders, the descendants of those who were around at the time of the New Zealand wars. What seems to be demanded is endless apology - whether in the sense of an endless number of apologies, or 
an unconditional apology, unbounded by the physical reality of the irreversible passage of time. Apology is figured as a kind of symbolic capital subject to the economics of scarce resources and depleted by too much asking. Brash appeals to the commonsense, everyday logic of apology as the expression of a state of internal regret for one's own guilty behaviour. For the political purpose of galvanising white backlash, he then implants the idea that Pakeha are being impossibly asked to 'take it personally'.

The actual conditions of Treaty apologies are rather different from those projected by Brash. In reality, Maori have made no call on Pakeha to apologise, although, as I will discuss further below, in settlement agreements the Crown does routinely apologise on behalf of New Zealanders. It does not suit Brash's purpose to clarify the distinctions that could be drawn between a Crown apology (the Crown apologising for its own acts or omissions), a national apology (the Crown apologising on behalf of the people of New Zealand), and a collective apology (in which members of civil society develop their own ways of adopting and supporting national apologies). There is little risk of a 'limitless' apology as such, given that the Crown apologises for specific acts and omissions in the circumstances of specific claimant histories. As tends to be the case in the restitution of widespread and repeated injustice, the apology implicitly recognises the impossibility of full restitution, in the sense of restoring the injured party to the status ante quo; in a sense, an apology echoes in the gaps between what is, what was and what might be. Thus we can accept that settlements must remain 'only a gesture' in some fundamental sense, while rejecting the slighting tone that Brash's choice of words suggests.

Brash's statement echoes that of a trans-Tasman counterpart with whom he shares a number of political sympathies, John Howard. In April 1997, the Liberal coalition government was called to negotiate with the Aboriginal and Torres Strait Islander Commission the wording of an official apology for the federal government's role in legislating for the forced removal of aboriginal children from their homes (Human Rights and Equal Opportunities Commission 1997: Appendix 9). ${ }^{5}$ In May 1997, at the reconciliation convention held to celebrate the 30 th anniversary of the Australian referendum that empowered the federal government to legislate for the indigenous population, Howard instead tendered a personal expression of regret carefully worded to fall short of full apology:

Personally, I feel deep sorrow for those of my fellow Australians who suffered injustices under the practices of past generations towards indigenous people. Equally, I am sorry for the hurt and trauma many 
people here today may continue to feel as a consequence of those practices (Howard 1997).

Similar wording, substituting the House's 'deep and sincere regret' for personal sorrow, appeared as part of the government's Motion of Reconciliation moved in the House of Representatives two years later, with Howard keen to obtain at least a façade of national unity for the looming Sydney Olympics and centenary of Australian Federation (Hansard 26 Aug. 1999: 9205). In reply to the motion, leader of the opposition Kim Beazley argued that a half-apology was no apology at all, a view shared by Aboriginal leaders, and noted that all other State parliaments had already managed to table suitably-worded apologies.

Hodge and O'Carroll (2006:117) have noted that in this pronouncement Howard splits himself neatly in two. As an individual he sympathises, but cannot apologise because he did not personally authorise or perpetrate the removals. As Prime Minister he also cannot apologise, because he represents the present generations of Australians who, in his view, should not be held accountable for actions and policies over which they had no control. In rejecting apology in his representative capacity, Howard appealed to a populist and synchronic conception of representation by purporting to express the will of 'all fair-minded Australians today'. At the same time, he must protect them from unjust accusations. Were Howard to apologise - to extrapolate from his perspective - then he would, by proxy, make history inappropriately 'personal' for the Australian 'mainstream' whom he considers his core constituency.

Yet the conundrum of apology that Howard presents as a question of fairness for today's generations could also have been resolved in a diachronic understanding of representation, in which the Prime Minister serves as agent for the Crown viewed conventionally as a continuous, impersonal legitimating authority for executive government. In New Zealand, Crown apologies to Maori are an innovation of the 1990s, as (to my knowledge) apologies were not included in earlier settlement Acts or statements from the throne. ${ }^{6}$ However, the practice has quickly become standardised, as set out in the Office of Treaty Settlements framework for Treaty settlements Ka Tika a Muri, Ka Tika a Mua: Healing the Past, Building a Future (1999). Apologies are apparently offered irrespective of any request by the claimant group (Bellingham 2006:142-3). However, these apologies may also be valued by Maori when delivered in appropriate form and circumstances (Joseph 2005: 265; Bellingham 2006:137). In the Pakeha sense of the Crown as a bureaucratic institution rather than charismatic authority, the fact that injustices are historical makes apology easier, in the sense of entailing less loss of face, or perceived expense of symbolic 
capital. This logic underlies the comic force of Chris Slane's cartoon (figure one, below). It depicts Prime Minister Helen Clark basking in the satisfaction of having apologised to the Samoan people for bringing influenza to the islands on the SS Talune in 1918 and for the actions of New Zealand police in 1929, with the speech caption, 'it's so easy to apologise for other people's mistakes'. While I do not admire Howard for his stance, it is possible to see it as a form of ethic: perhaps it is because Howard felt apology to be exceptional, rather than bureaucratically routine, that he stumbled over it.

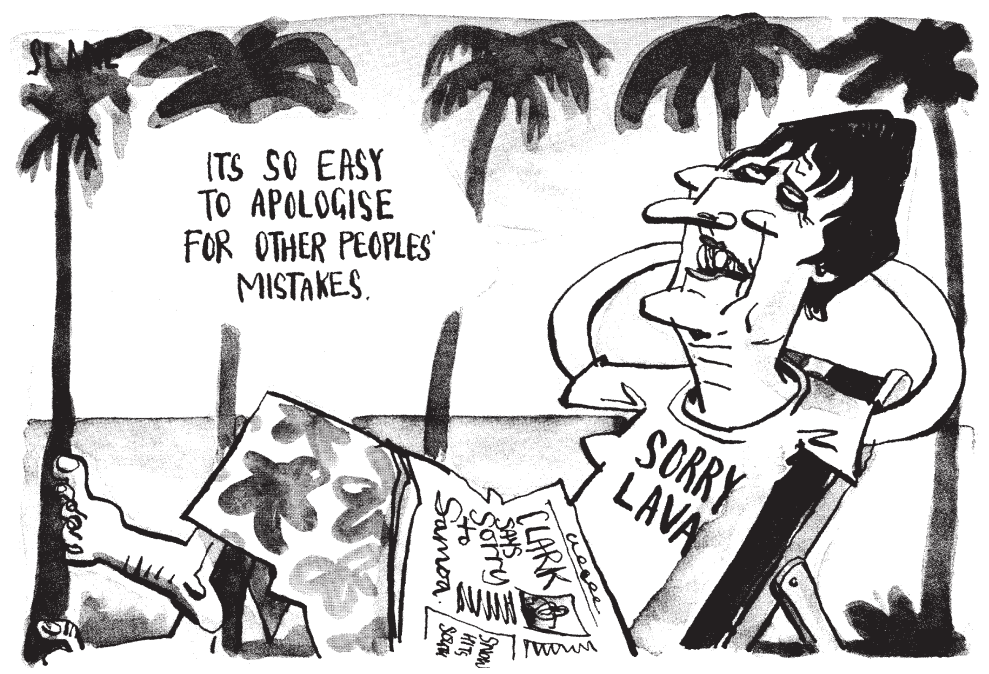

Figure 1: Cartoon by Chris Slane (2002)

Howard's reluctance to apologise provoked further expressions of public support for survivors of the stolen generations. Sorry Books were drawn up and presented to local indigenous communities on Sorry Day, established as one of the recommendations in the Bringing Them Home report (the commemorative day was renamed the National Day of Healing in 2005). Reasons for and against apology were debated online (see Lecouteur 2001); an online petition received 1741 entries (National Sorry Day Committee); and the television show The Games featured a model apology, coincidentally delivered by an actor who shares the same name as the Prime Minister. These grassroots expressions of support, sympathy, and shame - from white Australians, new immigrants, and some indigenous Australians - were addressed primarily to those who suffered under the practices of forcible removal, but no doubt they had a secondary aim to embarrass Howard, as if their implicit message was, 'See? If we can 
say sorry, so can you'. Amid the many official and community expressions in support of the stolen generations, Howard's apology became, so to speak, the one apology to rule them all.

Howard's Liberal government buckled in the 2007 federal election, and incoming Prime Minister Kevin Rudd swiftly fulfilled his party's pre-election commitment to apologise to the stolen generations by making it the first item of business for the new Parliament on 13 February 2008. The wording of the apology had been negotiated with indigenous leaders. In his speech, Rudd apologises for the oppressive laws and policies of successive Parliaments and governments, acknowledges the pain and suffering of the broken families, and pledges to close the gaps in material wellbeing between indigenous and nonindigenous Australians. He asks, but does not assume, that the apology be received in the spirit of healing. The Labor government took legal advice that the apology would not in itself entail liability to pay compensation to members of the stolen generations and their descendants. However, it does put further moral pressure on Australian governments to circumvent the piecemeal and largely unsuccessful process of claims through the courts by offering Stateadministered compensation packages. ${ }^{8}$

As a representative of a wider constituency Rudd uses the first person plural pronoun, 'we', in his formal apology. However, the referent of this pronoun is deferred, remaining unspecified until it is finally named in the tenth sentence as 'we the Parliament of Australia' (Rudd 2008:167). Thus, while the wording does not explicitly interpolate any wider collective such as 'the nation' or 'non-indigenous Australians', it does permit a pronomial opening by which members of the public might adopt the apology and its sentiments as their own. In his elaborating on the apology, Rudd expressly endorses the nation's intergenerational responsibility: 'As has been said of settler societies elsewhere, we are the bearers of many blessings from our ancestors, and therefore we must also be the bearer of their burdens as well' (Rudd 2008:170). In subtle ways, the rhetoric of the apology bridges the gap between the private subjects of civil society and the political institutions and agents of State that authorised and committed the removals.

The groundswell of organic community support that rushed to fill the symbolic vacuum left by Howard's obstinacy, leading eventually to Rudd's apology, is astonishing when compared to the carefully managed, confidential, and heavily bureaucratised machinery of Treaty negotiations in New Zealand. The Sorry Day rituals spoke of a desire to build relations of empathy between nonindigenous settler society and indigenous Australians. To my mind, this factor 
makes the Sorry Day rituals distinctive in testing the boundaries between the moral responsibility of settler society and that of the State. The apology debates in Australia prompted an intense round of self-interrogation on the part of some settler Australians, perhaps comparable to the foment of bicultural consciousness raising among Pakeha during the 1980 os. However, Treaty settlements as an institutional process concern historical and contractual relations between the Crown and government-recognised claimant groups. There is no place, no need, and little effort to engage settler identities in this process. ${ }^{9}$ Settlement apologies function predominantly as a symbolic imprimatur accompanying the mechanism of asset transfer, rather than being upheld as a (potentially) unifying force for the nation as a whole. The Australian case is thus of particular interest in investigating how settler identity politics may have been realigned by the phenomenon of collective apologies.

RECOVENANTING THE SOCIAL BOND: POLITICAL CULTURE

In a thoughtful article about how to acknowledge and represent the Japanese military's sexual enslavement of Korean women during World War Two, Chizuko Ueno discusses issues of collective responsibility that can be broadened to comparable postcolonial situations. As a Japanese woman, she is a citizen of the state that authorised and arranged mass crimes against Koreans. Although not a perpetrator, she identifies as a member of the perpetrator nation. She is also a feminist, one committed to commemorating and advocating for the victimised women in a manner that is sensitive to their needs. To ask for their forgiveness, she writes, would evacuate her individual subject position in a too-ready identification with the Japanese nation. Conversely, to represent herself as a concerned, politically motivated 'world citizen' would betray the national affiliation which she feels, however ambiguously; it would also deny the fact that those Koreans who still feel the humiliation of the war will see her as Japanese, making her nationality visible where she may prefer to neutralise it. Ueno poses the question of cross-national empathic advocacy this way:

Clearly we need something neither 'nation' nor 'individual'. How can 'I' take responsibility as an 'I' without being swayed by either of these poles? 'I' am built from the union of gender, nationality, occupation, position, race, culture, ethnicity and countless other relations. Each of us is faced with the question of how to cope with this multilayered 'I' and how to form bonds with others. There is no simple answer. But at least by posing the problem this way, we are given some basis to seek criteria for judgment (1999:148). 
She concludes that 'the responsibility of the state is not "my" responsibility, but conversely, absolving the state of responsibility does not absolve "me" (1999: 149).

In response to the kinds of issues raised by Ueno, Danielle Celermajer offers a persuasive interpretation of the apology movement in Australia. She states her purpose in writing as how to make sense of 'the empirical fact that an apparently private, emotional act emerged in the public sphere of politics, and continued to attract popular support even in the face of strong and "reasonable" normative objections' (2006:176). Celermajer's argument is premised on an interpretation of historical evidence - which she does not set out in any detail - that white Australians countenanced the forced removals of children within an ambiguous moral context in which separation was considered by many the right thing to do (2006:158). Celermajer does not raise this point to exonerate white Australians from their complacency. Instead she pursues the argument that those who supported the apology movement appreciated that the wrong to be addressed was Australia's pervasive political culture, rather than the set of discrete acts causally leading to the removals. As the authors of the Bringing Them Home report make clear, ordinary members of the public did not devise the policy of removal, legislate for it, and commit the removals, but they did help to set the broader norms and beliefs about right and wrong that underwrote an extensive, society-wide denial of indigenous humanity. In this circumstance, the affect motivating the sense of collective responsibility seen in Sorry Day activities is not guilt, directed toward actions, but rather a legacy of national shame, directed toward a chastened sense of self. Australians who supported the apology movement could thus adopt the formal parliamentary apologies as their own, implicitly endorsing the principle that 'every person is co-responsible for the way he is governed' (Karl Jaspers, cited in Celermajer 2006:165). As one aspect of a multi-levelled reparation programme, Celermajer concludes, apology can inscribe the memory of terrible events, enact a commitment never to allow such abuses again, and '[provide] a means for Australia to explicitly shift its political culture' (2006:176).

Celermajer recognises that this concept of collective responsibility is readily compatible with religious rituals of repentance, and it is important to elaborate on her claim in the light of other commentators who find reconciliation discourse too religious, on one hand, and not religious enough, on the other. Both prongs of this critique can be found in Jacques Derrida's meditations on the closely related topic of forgiveness (Derrida 2001). Generally he regards conciliatory movements in global affairs in a positive light (it would be churlish to take a stand against conciliation, as such). He does, however, reject the way in 
which conciliation discourse spreads the 'Abrahamic language' of the religions of the book, particularly Christianity, irrespective of whether the societies in question are predominantly Christian (28). More fundamentally he objects to what he sees as the undermining of the inherently sacred power of forgiveness uttered in its very name. Once forgiveness is demanded for political advancement, for collective therapy, or in the terms of a calculated exchange, it loses its essentially personal, aneconomic, absolute, and unilateral qualities - qualities that figure the divine origins and purposes of forgiveness. Thus 'the simulacra, the automatic ritual, hypocrisy, calculation, or mimicry are often a part, and invite parasites to this ceremony of culpability' (29).

For some critics of the Australian apology movement, an objectionable 'economic' calculation inevitably takes place in collective apologies, further entrenching the dominant interests of settler society. For example, Haydie Gooder and Jane Jacobs suggest that the implicit logic of formal apologies is transactional, even when they do not ask forgiveness in explicit terms (Gooder and Jacobs 2002). For these writers, deep anxieties structure and undermine the apparent postcolonial commitments of settler culture, and apology is presented not as a dignifying process, but a kind of spurious self-abasement in line with settler culture's self-imposed sense of negativity in relation to the 'moral positivity' of the indigene (212). To paraphrase somewhat crudely, but not, I think, inaccurately, the deal would run something like this: we (leftleaning, well-meaning members of settler society) attribute to indigenes the power of forgiveness and duly apologise to them; you (indigenes) forgive us and so extinguish our shame, restore our sense of proper belonging in the land, and transform us from "colonialist" into that fantasized subject of the postcolonial nation' (211). This melancholic yet self-serving postcolonial equivalent of Yom Kippur performs the ideological work of continually converting real indigenous losses (of land, economic resources, culture, children, language) into symbolic settler absence (of spiritual belonging in the new land) which demands to be constantly assuaged and reassured. ${ }^{10}$ Like most other commentators on the Australian apology debates, Gooder and Jacobs do not investigate what effect the apology movement had on stolen generation survivors or on the political bargaining power of indigenous advocacy groups, perhaps because they view apology as fundamentally self-regarding anyway (see further Morton 2003).

To my mind, the genius of Celermajer's philosophy of apology is that she admits the dimension of the sacred, but in a context that allows for a progressive politics that can be seen in alliance, rather than competition, with indigenous interests. I will try to explain this apparent paradox. Despite likening collective 
rituals of apology to civil religion, she does not interpret them as a request for forgiveness, even implicitly, and she steers away from questions of reception. In this sense, she offers a strangely intransitive or diffuse account of collective apologies. An apology may indeed be paired with a corresponding statement of forgiveness, as has been announced in a recent Treaty settlement development, the Taranaki Whanui (Wellington) agreement in principle, which was announced on 13 December 2007. And perhaps, speculatively, we could interpret some State apologies as belated reciprocity for unilateral expressions of forgiveness on the part of an aggrieved ethnic group. ${ }^{11}$ But a formal apology need not explicitly ask for forgiveness, or even necessarily imply such a request, to take effect as a reformulation of political culture. Following the van Boven principles for restitution which underwrote the Bringing them Home recommendations, Celermajer is careful to frame apology as one of the elements of satisfaction for the injured party in objective terms; it is not judged by whether its addressees feel satisfied in a subjective sense.

Celermajer's primary interest lies in an analysis of settler-State relations, encompassing both social and political institutions, rather than settler-indigenous interaction. Unlike Gooder and Jacobs, she does not pursue the view that the underlying motivations of the apology movement for white Australians were to secure legitimacy for occupation of the land (from a political perspective), and to earn the right to be loved (at an affective level). While Celermajer does appeal to the Judeo-Christian language of covenant, she orients this concept toward a mode of solemn commitment between civil society and government, rather than atonement between settler and indigene. In this way, she restricts her analysis of collective apology to those elements which resonate most fully with the model of a social contract; as she notes, her aim is not to attack jurisprudential liberalism but to partner it with other discourses that give it better effect. The five-fold promise to build a more equitable future, included in the last five sentences of the formal apology delivered by Rudd, tends to support Celermajer's interpretation of collective apologies as commitment rather than expiation. Derrida's fear that the era of apology imposes Christian values on non-Christian cultures is thus mollified to some extent in the Australian case. Certainly the language of international rights draws deeply on Christian tradition, as Derrida argues, but the purpose of collective apologies need not be directed solely or primarily to a self-interested restoration of the moral balance sheet.

As I implied earlier, the absence of a comparable non-indigenous apology movement in New Zealand suggests that Crown apologies delivered in the formal proceedings of Treaty settlements tend to be contained to the government- 
indigene axis of relationship. The religious dimension of apology also takes a specific cast in the New Zealand context, as a (nominally) secular state encounters the syncretic Christian culture that is widespread in tribal Maoridom. When representatives of the Crown 'seek to atone' for the wrongs of the Crown, to use a phrase that regularly appears in such apologies, we find not merely a conventional recourse to moribund religious ritual, but, more substantially, a bicultural recognition of Maori spirituality. Derrida's formulation of 'a process of Christianisation which has no more need for the Christian church' (2001:31) can also operate in reverse. It is in part through the post-secular partnering of religion as a premodern discourse - first forced on Maori through colonisation and now reclaimed and revoiced by them - that a modern discourse (such as 'self-determination') may be realised. ${ }^{12}$

\section{TRANSGENERATIONAL MEMORY AND TRANSFERENTIAL HISTORY}

The self-in-political-community that Celermajer theorises as the subject of collective apologies is one of the countless relations of self through which bonds with others may be formed. It gestures toward a new mode of subjectivity mooted by Ueno, one that might emerge in the interstices between 'nation' and 'individual'. But there remains the additional complication of how to create and maintain such bonds through history as well as across collective identities. Because collective apologies tend to imply some concept of transgenerational responsibility, debates about apologies almost inevitably implicate controversies about the present day meaning and effects of past events. Here some form of mediation might be found between the time-bounded individual of liberal philosophy, and a conception of the subject as a culmination of multiple strands of inheritance, including familial, ethnic and national filiations.

Those who are wary of collective apologies also tend to resist any notion of a transgenerational subject, at least as it pertains to memories of events in national history that evoke shame or regret rather than pride. In his Orewa speech of 2004, Brash advises that 'there is a limit to how much any generation can apologise for the sins of its great grandparents'. Since Brash doesn't specify what this limit is, the vagueness invites a figurative reading of his words as understatement: his audience may, with some justification, understand Brash to mean that apologising today for yesterday's wrongs cannot be justified under any circumstances. Furthermore, the echo of the Old Testament threat that the sins of the fathers will be visited upon the sons connotes that collective apologies are archaic, backward-looking and punitive. They revivify events and feelings that ought to have been buried by history. In a closely related axis of controversy, collective apologies may be regarded as a symptom of the malaise 
of presentism, the practice of interpreting and judging past events according to the moral norms of today. Here, troublesome events of the past are not deemed to be superceded by time and progress, as Brash might prefer, but rather were not troublesome at all - or only ambiguously so - when weighed in terms of the prevalent ideas of their day. Either line of argument can be mobilised in politically reactionary ways to neutralise aspects of the past that are perceived to destabilise overriding goods such as national unity or formal equality.

Efforts to contain the past may equally preoccupy pro-apology spokespeople, but in the rather different sense, derived from psychodynamic culture, that hurts of the past continue to agitate pathologically in the national polity until they are healed. Tom Calma, Aboriginal and Torres Strait Islander Social Justice Commissioner for the HREOC, articulates this view when he argues that the retraumatisation that members of the stolen generation underwent in testifying to the Commission of Inquiry continues because of the Howard government's hostility towards findings of the Bringing them Home report (Calma 2007). Calma's comment implies that the ongoing force of the past is a function of its reception in the present; the past is not 'closed' merely by narrating events as such, but only by receiving and responding to that narration with compassion and a full appreciation of the scale of the injustice.

In juxtaposing Brash and Calma as representative voices of two very different attitudes towards the role of the past in the present, I am sketching a distinction between those who desire a tidy detachment from the past, and those who feel not only that such detachment is impossible, but also that their identity may be overwhelmed by events of the past that continue to overshadow present experience. In the former representation, the regrettable wrongs of the past are deemed to be wholly contained by the bulwarks of a sense of proportion and the mitigating circumstances of historical context; in the latter, the hurts of the past remain traumatically unbound and at large. Historian Dominick LaCapra has likened the former objectivist stance to 'bystander' history, which positions the observer independently of events (LaCapra 1998: 48). Although it purports to protect the past from the political pressures of the present, bystander history effectively works to insulate the present from the ructions of the past. LaCapra finds this model of historical representation limited in any case, because it discounts transferential relations: the fact that we are touched personally by what we learn about the past, even when (or particularly when) denying that such reactions exist. However, objectivist history is particularly inadequate as a response to historical events that offend against the bounds of common humanity. Here he advocates for an ethical position that he terms 'empathic unsettlement', 'a desirable affective dimension of inquiry that com- 
plements and supplements empirical research and analysis' (1999:722). ${ }^{13}$

Borrowing by analogy from Ueno's mooting of a subjectivity that is intermediate between individual and nation, we can now ask whether it is possible to realise a settler historicity that achieves a similar mediation between history and memory. A self-in-social memory would be sensible to - neither immune to, nor consumed by - the ongoing but not determinative impact of the 'sins of our great grandparents'. This mediation refuses an ethnically binarised sentiment that settler cultures 'have' history while indigenous cultures 'have' memory. Likewise, it endeavours to avoid the trap of believing that settler cultures are plunged into a debilitating 'memory crisis', racked psychologically by their self-imposed amnesias. It is possible instead to view collective apologies as one way of activating a sense of transgenerational subjectivity, or a sense of self within a cultural inheritance perceived as the fabric of contemporary experience. The practice of collective apologies may thus rebalance the relation between past and present through a double movement. In bridging past and present, collective apologies counteract those who find it politically convenient to keep them separate. In this sense, apologies can help to incorporate historical events into national memory, making them a living component of ongoing relations between settler society, State, and indigenous communities. On the other hand, apologies can help to therapeutically distance (without exorcising) the past for those who value them as one aspect of a multifaceted process of conciliation and working-through.

\section{CONCLUSION}

In response to Montgomerie's question posed at the outset of this paper, it seems clear to me that collective apologies do engage matters of considerable intellectual substance. If it seems astonishing that just two words - 'we apologise' - can sustain so many waves of analysis, that is because they symbolically condense so much freight of indigenous social, political and economic aspirations and settler anxieties about shifting dispensations of power in postcolonial countries. When offered as part of a wider set of restitutive policies, apologies represent an always imperfect attempt to accommodate competing accounts of justice, community and history. If apologies may be offered out of self-interest on the part of those who represent or identify with perpetrators - whether in the name of social cohesion, national unity, full and final settlement, or the assuaging of a sense of settler guilt - that does not in itself preclude the gaining of political leverage on the part of those who receive apologies. Nor do we need to hail the age of apology as some revolutionary dawn in order to see in it glimmerings of revision to liberal Western understandings of political 
responsibility and social memory. The apology movement in Australia included a widespread sentiment that the 'hearts and minds' of non-indigenous Australians must be won over to support indigenous Australians in their cause, while in New Zealand, Treaty settlements and apologies have perhaps rather been the result of, rather than the occasion for, bicultural alliances. However, in each case the practice of apology signals the opening of new doors in postcolonial relations.

\section{NOTES}

1 I have borrowed the phrase 'Age of Apology' from Beauchamp (2007) in what I intend as a neutral re-accenting of his more cynical tone.

2 I am using the term 'settler society' as shorthand for a more specific constituency, which is British-descended settlers who believe in substantive racial equality. As a self-designation the term 'Pakeha' often implies these values, but there is no single equivalent term in the Australian ethnoscape.

3 In Psychoanalytic Culture (1997), Parker argues that psychoanalytic principles structure contemporary Western culture, particularly in Continental and American contexts. Although psychodynamic culture derives in part from Freud's earliest studies on hysteria, it is distinct from psychoanalysis proper, in part because Freud never theorised the concept of counter-transference. The concept of 'healing' is also, of course, antithetical to psychoanalysis.

4 Don Brash became leader of the National Party in October 2003. His Orewa speech announced the party's policy on race relations, including Treaty negotiations, based on a 'one law for all' concept of formal equality. His performance is partly credited for National's rejuvenation in the 2005 general election, where it fell just 2 percentage points short of the Labour Party in the bid to form a government. Brash's intervention on race relations was also instrumental in the Labour coalition government's withdrawal from its 'closing the gaps' policy of 2000 , which had provided $\$ 184$ million in new funding for community programmes intended to raise Maori and Pacific wellbeing in health, housing conditions, employment and education. Although many such programmes continue, they do so under revised eligibility criteria emphasising need rather than race.

5 Here and in the following paragraphs, I am condensing the more detailed chronologies of the events relating to the stolen generations apology debates given in Schaffer and Smith (2004) and Augoustinos et al. (2002). 
6 Apologies were not included in the Waikato-Maniapoto Maori Claims Settlement Act 1946, the Taranaki Maori Claims Settlement Act 1944, or the Ngaitahu Claim Settlement Act 1944. In her speech at Waitangi in New Zealand's 1990 sesquicentennial year, Queen Elizabeth II noted that the Treaty of Waitangi had been 'imperfectly observed' but did not apologise. On her return visit in 1995, the Queen became the first British monarch to make an apology, at least in writing, by signing the Waikato Raupatu Claims Settlement Act 1995 into law. Some Maori were angered that Pakeha Queen did not travel to Ngaruawahia to deliver the apology to Te Arikinui Dame Te Atairangikaahu.

7 The full text of actor John Howard's apology is included as an appendix to Damien Grace's article 'The Question of an Apology: Reconciliation and Civility' (Grace 2001).

8 The Howard government refused to implement recommendation 14 of the Bringing Them Home report calling for compensation to those affected by the forced removal policies, although an \$AU63 million package was provided for family tracing and counselling services, an oral history project culminating in the publication Many Voices: Reflections on Experiences of Indigenous Child Separation (2002), and to address other recommendations of the report. I am aware of only one successful legal claim for compensation to date: in Trevorrow v State of South Australia (SASC 285, 1 Aug. 2007) the Supreme Court of South Australia awarded \$AU525,000 to a man who had been sent at 13 months old from hospital to a foster home without his mother's knowledge. Documentary records confirmed that State agencies lied outright to the mother when she queried the whereabouts of her child. In an earlier case, Lorna Cubillo \& Peter Gunner v The Commonwealth (FCA 1084, 11 Aug. 2000), the Federal Court of Australia ruled, and was upheld on appeal, that the federal government was not legally liable in part because of the completeness of its delegation of powers to other agencies (see the commentary provided in van Krieken [2001]). In 2006 the State of Tasmania set aside \$AU5 million for compensation payments.

9 The New Zealand Herald editorial of 8 June 2004 suggests in passing that Brash's Orewa speech achieved a wide impact partly because of a public perception that debates about Treaty issues have been somehow hushed up: 'If Treaty issues had been debated much more frankly over the past 20 years, Dr Brash might not have been handed such a potent cause' ('No Apologies'). The implication is that festering Pakeha resentment at feeling 'shut out' from Treaty issues found release through Brash's statements. The Herald then adds that more moderate views are likely to follow once Brash's views are measured and evaluated more carefully. 
10 My phrasing here echoes Dominick LaCapra's distinction in 'Trauma, Absence, Loss' (1999) between loss, which can in principle be wholly or partially restored, and the existential quality of absence, which cannot.

11 I have in mind the ethos of forgiveness which suffuses Joy Kogawa's novel Obasan (1981), which was instrumental in the successful lobby movement leading the Canadian federal government to offer an apology and compensation package to Japanese Canadians sent to internment camps during World War Two.

12 I am here influenced by Vijay Mishra and Bob Hodge's finding in 'What Was Postcolonialism?'. Given that secular ideologies have failed to extend full political rights, they argue, 'the incomplete project of modernity ... is not a matter of breaking off completely with a premodern past, but of making the latter inhere in modernity as a significant and empowering trace' (Mishra and Hodge 2005:396).

13 I do not mean to imply that historians who hold to the principles of scholarly objectivity are inimical to political efforts to achieve settlement and reconciliation. Indeed, detailed examinations of colonial land transactions and confiscations have been invaluable to settlement preparations and Waitangi Tribunal investigations, notwithstanding the caveats that historians such as Giselle Byrnes and W. H. Oliver have raised about the distorting effects of representing history within these legalistic and overtly political contexts.

\section{REFERENCES}

Ahmed, S. 2004. The Cultural Politics of Emotions, Edinburgh: Edinburgh University Press.

Antze, P. and Lambek, M. (eds). 1996. Tense Past: Cultural Essays in Trauma and Memory, New York: Routledge.

Augoustinos, M., Lecouteur, A. and Soyland, J. 2002. 'Self-sufficient Arguments in Political Rhetoric: Constructing Reconciliation and Apologizing to the Stolen Generations', Discourse \& Society, 13 (1):105-42.

Barkan, E. 200o. The Guilt of Nations: Restitution and Negotiating Historical Injustices, New York: Norton.

Beauchamp, G. 2007. 'Apologies All Around', American Scholar, 76 (4): 83-93. 
Bellingham, J. 2006. The Office of Treaty Settlements and Treaty History: An Historiographical Study of the Historical Accounts, Acknowledgement and Apologies Written by the Crown, 1992 to 2003. MA Thesis, Victoria University of Wellington. $195 \mathrm{pp}$.

Brash, D. 2004. 'Nationhood', Orewa Rotary Club, 27 January. http://www.national.org.nz/files/OrewaRotaryClub_27Jan.pdf

Calma, T. 2007. [Speech notes], Parliament House, Canberra, 21 May. http:// www.hreoc.gov.au/about/media/speeches/social_justice/2007/calma_sorry_day20o7.html

Celermajer, D. 2006. 'The Apology in Australia: Re-covenanting the National Imaginary', in E. Barkan and A. Karn (eds) Taking Wrongs Seriously: Apologies and Reconciliation, Stanford, CA: Stanford University Press: 153-184.

Derrida, J. 2001. On Cosmopolitanism and Forgiveness, trans. M. Dooley and M. Hughes, London: Routledge.

Gooder, H. and Jacobs, J. M. 2002. 'Belonging and Non-Belonging: The Apology in a Reconciling Nation', in A. Blunt and C. McEwan (eds) Postcolonial Geographies, New York: Continuum: 200-213.

Grace, D. 2001. 'The Question of an Apology: Reconciliation and Civility', Australian Journal of Human Rights, 4 http://www.austlii.edu.au/au/journals/ AJHR/2001/4.html

Hirst, J. 2006. Sense and Nonsense in Australian History, Melbourne: Black Inc. Agenda-Schwartz Publishing.

Hodge, B. and O'Carroll, J. 2006. Borderwork in Multicultural Australia, Crows Nest, Nsw: Allen \& Unwin.

Howard, J. 1997. Opening Ceremony Speech to the Australian Reconciliation Convention, 26 May, Melbourne. http://www.austlii.edu.au/au/special/rsjproject/rsjlibrary/car/arc/speeches/opening/howard.htm

Human Rights and Equal Opportunities Commission. 1997. Bringing them Home: The Report of the National Inquiry into the Separation of Aboriginal and Torres Strait Islanders from their Families. http://www.austlii.com/au/other/ IndigLRes/stolen/index.html 
Joseph, R. 2005. 'Denial, Acknowledgement, and Peace-Building through Reconciliatory Justice', in W. McCaslin (ed) Justice as Healing: Indigenous Ways, St Paul, MN: Living Justice Press: 253-74.

LaCapra, D. 1998. 'The University in Ruins?', Critical Inquiry, 25 (1):32-55.

— 1999. 'Trauma, Absence, Loss', Critical Inquiry, 25 (4): 696-727.

LeCouteur, A. 2001. 'On Saying "Sorry": Repertoires of Apology to Australia's Stolen Generations', in A. McHoul and M. Rapley (eds) How to Analyse Talk in Institutional Settings, London: Continuum: 146-58.

Marrus, M. R. 2006. 'Official Apologies and the Quest for Historical Justice', University of Toronto Munk Centre for International Studies, Occasional Paper no. 3. http://webapp.mcis.utoronto.ca/resources/MCIs_Controversies/2006_ CGPS3_Marrus_Official_Apologies.pdf

Mishra, V. and Hodge B. 2005. 'What Was Postcolonialism?', New Literary History, $36(3): 375-402$.

Montgomerie, D. 2003. 'Apologising for History - A Case Study of Media (Mis) relations', History Now, 9 (2):4-5.

Morton, J. 2003. 'Abortive Redemption? Apology, History and Subjectivity in Australian Reconciliation', Journal of the Polynesian Society, 112 (3):238-259.

National Sorry Day Committee. 'Petition: Say Sorry Prime Minister Howard'. http://www.nsdc.org.au/index.php?option=com_mospetition1

'No Apologies for Featuring Bishop's View'. 2004. [Editorial] New Zealand Herald, 8 June: A12.

Parker, I. 1997. Psychoanalytic Culture: Psychoanalytic Discourse in Western Society, London: Sage.

Rudd, K. 2008. 'Apology to Australia's Indigenous Peoples', Commonwealth of Australia House of Representatives, Hansard 13 February: 167-73. http:// www.aph.gov.au/hansard/reps/dailys/dr130208.pdf

Schaffer, K. and Smith, S. 2004. Human Rights and Narrated Lives: The Ethics of Recognition, New York: Palgrave Macmillan. 
Article $\cdot$ Lawn

Slane, C. 2002. [Cartoon]. NZ Listener, 15 June: 15 .

Trouillot, M-R. 200o. 'Abortive Rituals: Historical Apologies in the Global Era', Interventions, 2 (2): 171-186.

Ueno, C. 1999. 'The Politics of Memory', History and Memory, 11 (2):129-52.

van Krieken, R. (2001). 'Is Assimilation Justiciable? Lorna Cubillo \& Peter Gunner v Commonwealth', Sydney Law Review, 23 (2):239-6o. http://www-personal. usyd.edu.au/ robertvk/papers/cubillo.htm. 